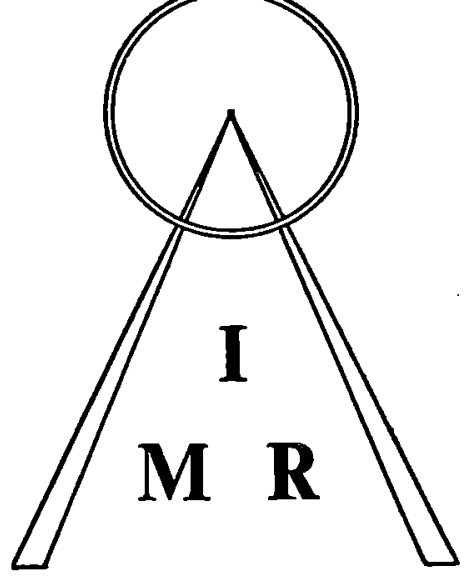

THE MINERALS INDUSTRY OF MOZAMBIQUE

Paul Jourdan

Report No. 117

June 1990 .

INSTITUTE OF MINING RESEARCH UNIVERSTYY OF ZIMBABWE
P.O. Box MP. 167, MOUNT PLEASANT HARARE, ZIMBABWE 


\title{
THE MINERALS INDUSTRY OF MOZAMBIQUE
}

\author{
By \\ Paul Jourdan \\ INSTITUTE OF MINING RESEARCH \\ University of Zimbabwe \\ Harare, June 1990
}

IMR Open Report Number 117

$\begin{array}{lr}\text { Introduction } & 1 \\ \text { Background } & 1 \\ \text { The Economy } & 1 \\ \text { The Mining Sector } & 3 \\ \text { General } & 3 \\ \text { Economic Geology } & 4 \\ \text { Legislation } & 5 \\ \text { Mineral Production } & 7 \\ \text { Discussion } & 14 \\ \text { Footnotes } & 16\end{array}$ 


\section{MOZAMBIQUE}

MINERALS

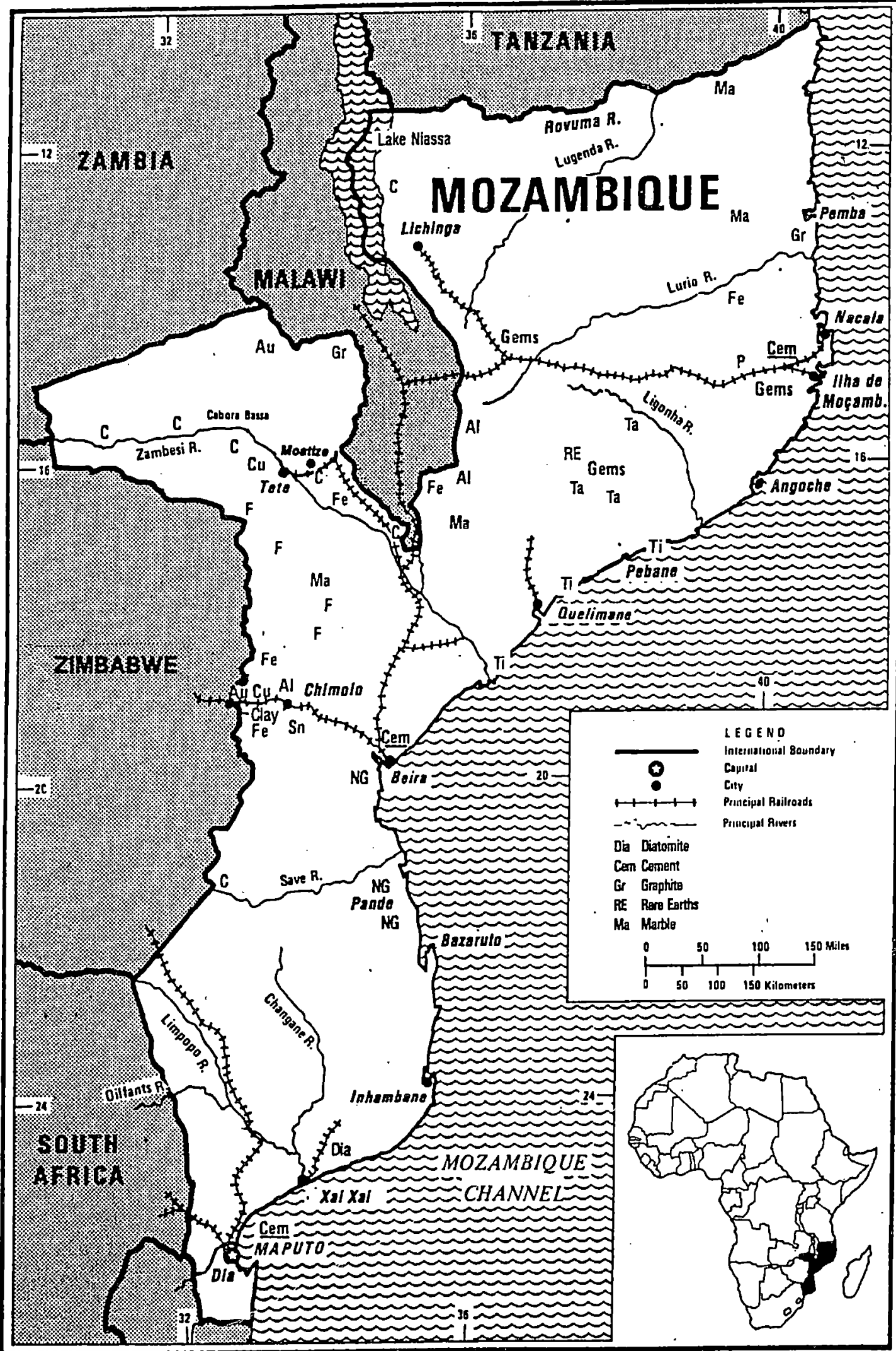




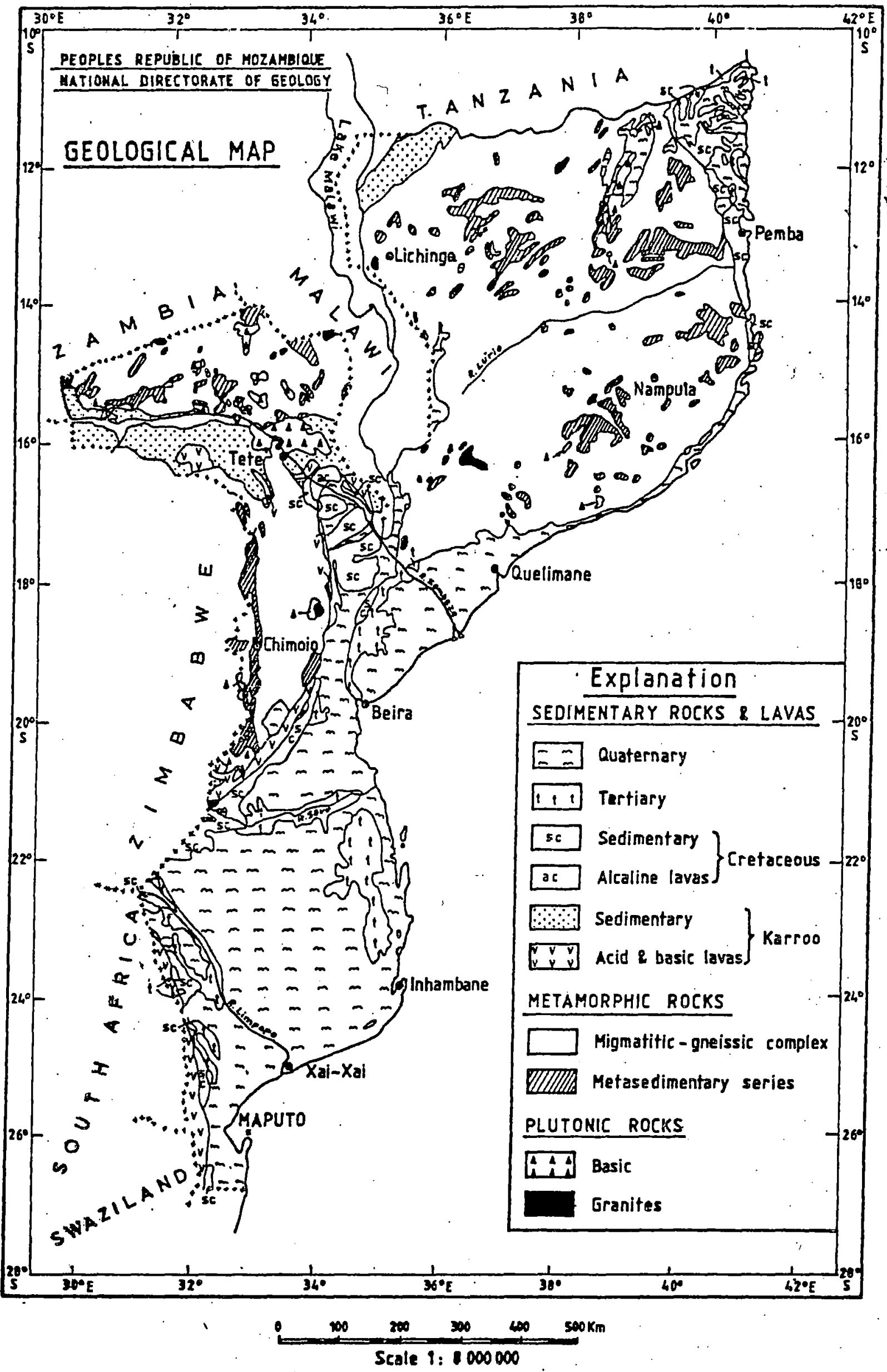




\section{The Minerals Sector of Mozambique}

\section{Introduction}

\section{Background}

The Island of Mozambique, whence the country gets its name, was an Arab trading centre, handling gold, ivory and slaves from the African interior. It was taken over by the Portuguese in the sixteenth century, who also occupied several other ports along the coast, but they did not colonise the hinterland until the last century. In the wake of the British and French decolonisation of Africa in the late fifties and early sixties, a nationalist movement, the Front for the Liberation of Mozambique (Frelimo), was formed in 1962 from several other organisations in Dar es Salaam in neighbouring Tanzania. In 1964 Frelimo launched an armed liberation struggle against the Portuguese who had made it clear that they were not at that time willing to follow the lead of the other major European colonizers by giving independence peacefully to their colonies.

By 1974 it had become apparent toa group of officers in the Portuguese army that theywere slowly losing their colonial wars and that the cost to the metropolitan economy was greater than the benefits derived from having an "empire". In April of that year there was a coup in Lisbon against the fascist government that had held power since the late twenties, carried out by officers from the colonial armies (the Armed Forces Movement, MFA).

\section{The Economy}

Following a ceasefire in 1974, The Peoples Republic of Mozambique (PRM) came into being on the 25 th June 1975 under Frelimo which inherited a backward colonial economy, dependent not only on Portugal but also on neighbouring white-ruled South Africa. In 1973 imports stood at 11.4 GMT (MT $=$ Metical) while exports were less than half this value at 5.54 GMT. Invisibles made up 3.5 GMT leaving a negative balance of -2.4 GMT. Most of the invisibles came from South Africa in the form of tourism, transport (ports and railways) and the repatriation of miners' salaries. In 1973 the port of Maputo handled 6.6 Mtonnes of cargo, mainly for South Africa, but by 1983 this had fallen to 1.1 Mtonnes and from 1973 to 1988 the number of Mozambicans working on South African mines fell from 100 thousand to 46 thousand.

From 1973, when it became apparent that the war was going badly, the 250 thousand Portuguese settlers started to leave Mozambique. In 1974 the exodus increased and after Independence in 1975 most of the remainder panicked. By the end of 1976 there were only a few thousand settlers left. Thus Mozambique had lost over $80 \%$ of its skilled technicians by the second year of Independence. This was the main contributor to the rapid economic decline in 1975, 1976 and 1977. By 1978 the slide had been halted and the economy once again started to show positive growth through to 1981, despite the undeclared war with the then Rhodesia which had started with the Mozambican imposition of UN sanctions in March of 1976 and continued with direct attacks and by fostering the MNR until the independence of Zimbabwe February 1980. The total cost of supporting the Zimbabwean struggle was estimated at 556 MUS\$ in 1983, more than the total export earnings over the three years 1977 to $1979^{1}$.

From 1981 the economy once again went into decline, this time due to South African destabilization, both direct and indirect via the now South African run MNR (Mozambican National Resistance) bandit activities. In March 1984 Mozambique and South Africa signed the, now infamous, Nkomati Accord whereby Mozambique would cease to allow its territory to be used by the African National Congress (ANC) to infiltrate South Africa and, in exchange, that country would cease training and supplying the 
MNR bandits. But there has been ample evidence proving that South Africa has continued to run the MNR, at least until 1989, even though Mozambique has kept strictly to its side of the bargain. In 1986 the Mozambican President, Samora Machel, was killed in a plane crash, with half of the cabinet, on the South African side of the border, near Maputo, which is widely believed to have been engineered by the South African security system using a false beacon. By 1988, according to the World Bank, Mozambique was the poorest country in the world with a GNP per capita of 100 USD $^{2}$ compared to 2501988 USD in 1980 , a fall in real terms of $60 \%$; and the national external debt had risen to 4.4 GUSD, a staggering $353 \%$ of GDP.

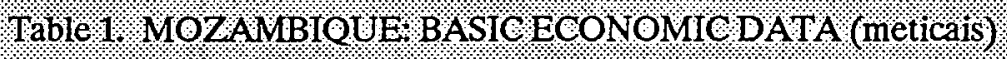

\begin{tabular}{|c|c|c|c|c|c|c|c|c|c|c|}
\hline & & & & & & 84 & & & $28^{\circ}$ & \\
\hline 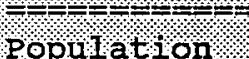 & x. & 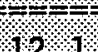 & 92. & & & & & & & \\
\hline $8 \mathrm{p}$. & $1 / \mathrm{m}$ & 15 & 16 & 16 & 17 & 17 & 17 & 18 & 18 & \\
\hline & USD & 32.4 & 35.4 & 37.8 & 40.2 & 42.4 & 43.2 & 40.4 & 289 & 529 \\
\hline & & 100 & 102 & 20 & 1.55 & & & 2 & 53 & 143 \\
\hline $\mathrm{DP}$ & $\mathrm{G}$ & 70 & $7 \%$ & $8 \%$ & 83 & 100 & 147 & 167 & 428 & 6.60 \\
\hline $\mathrm{SP}$ & USD & 179 & 165 & 171 & 155 & 172 & 246 & 291. & 102 & 8. \\
\hline C & $\mathrm{G}$ & 1 & 1 & & & 11. & 10 & 16 & 102 & 214 \\
\hline & 8 & & & & $1 / 18$ & 1918 & 178 & 16108 & 248 & \\
\hline ebt. & GUSD & 2 & 2 & 3 & $1.17 \%$ & 1.22 \% & $3,04 \%$ & 3,52 & 4.35. & $4 \% 47$ \\
\hline Debt $/ G$ & 8 & $12 \%$ & $11 \%$ & $15 \%$ & 578 & $52 \%$ & $90 \%$ & 858 & 2948 & 353 \\
\hline Govt Revenue & $\mathrm{G}$ & 15 & 18 & 21 & 22 & 22 & 19 & 22 & 69 & 131 \\
\hline
\end{tabular}

\% gross fixed capital formation . IMR SADCC Databank, 1990 .

Since 1985 the security situation improved in the centre of the country where Zimbabwean troops are deployed to guard the Mutare-Beira corridor and in 1988 Malawi agreed to stop allowing the bandits transit from South Africa as they had lost both their rail export routes, to the ports of Nacala and Beira, due to bandit activity. From 1987 the government has implemented an economic recovery programme $\left(\mathrm{PRE}^{3}\right)$ entailing a massive devaluation of the currency which has led to super-inflation and a substantial fall in the purchasing power of wages, but the economy has started to show modest growth, albeit from an extremely low starting point. In 1989 the government entered into talks with the MNR in an attempt to stop the war but they came to nothing and in 1990 they announced that open multi-party elections would be held in which the MNR was free to participate.

Mozambique's main exports have always been agricultural. In 1973 they were cotton $20 \%$ of exports, cashew nuts $18 \%$, sugar $10 \%$, wood $5 \%$, petroleum products $5 \%$, tea $4 \%$, copra $4 \%$ and prawns $2 \%$. By 1988 the principal exports were prawns $43 \%$, cashew nuts $26 \%$, cotton $5 \%$, sugar $5 \%$, and copra $4 \%$. The banditry in the countryside has made it difficult for crops to be planted and marketed which is in part responsible for the ascendance of prawns as the main export, as it is a relatively "bandit free" product. In addition, since the closure of the Matola oil refinery in 1984 no exports of petroleum products have been made. Although South Africa is the main source of non-aid forex, this is mainly in the form of remittances of migrant miners, which were $70 \%$ of the value of exports in 1988, rather than direct trade. From 1980 to 1988 South Africa accounted for $6 \%$ of exports and $11 \%$ of imports. 
Table 2. MOZAMBIOUE.TRADE AND MIGR ANT LABOUR (meticais)

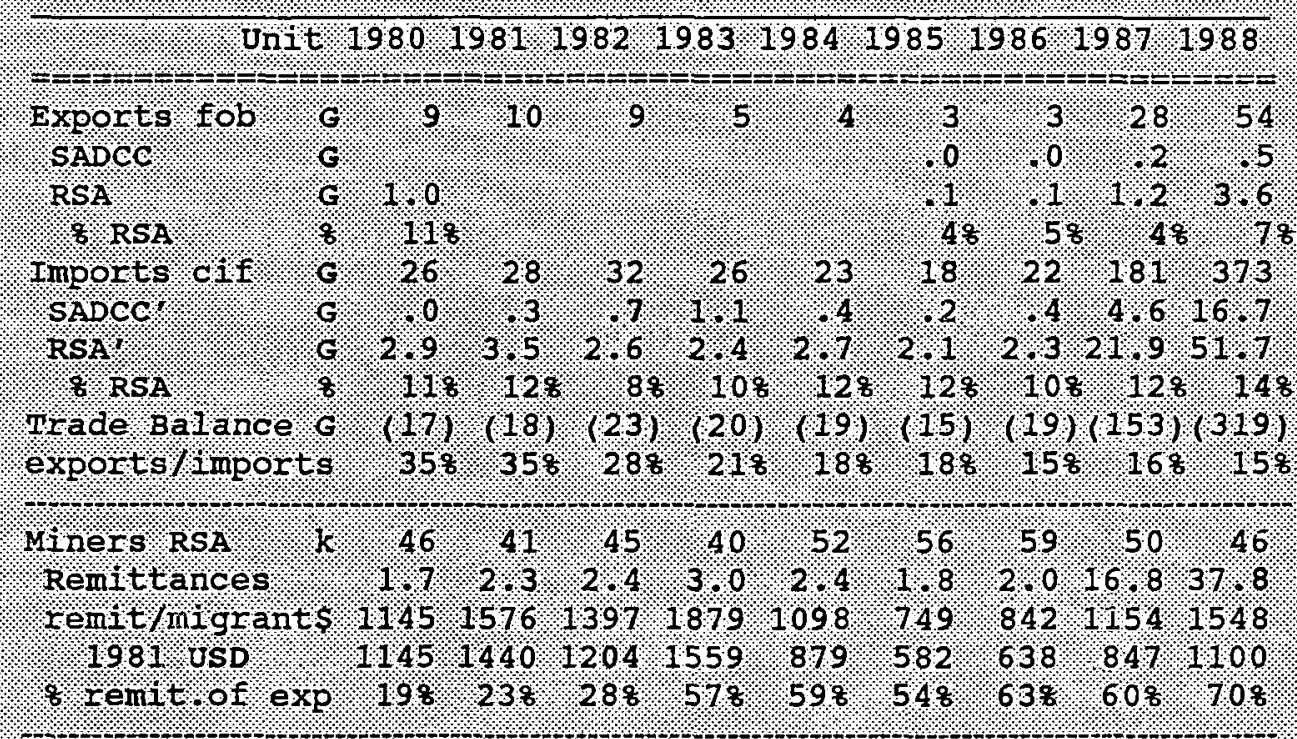

Source TMR SADEC Databank, 1990 .

\section{The Mining Sector}

\section{General}

The mining industry of Mozambique has always been tiny in comparison to other coun tries in the region, but even so it has shrunk substantially since 1981, when the effects of the South African sponsored banditry were first felt. In 1981 mining contributed $0.8 \%$ of the country's GDP and $4 \%$ of national exports. By 1988 these contributions had fallen to $0.2 \%$ and $2 \%$ respectively, mainly due to the effects of banditry as mines tend to be more isolated than other sectors of the economy.

Táble 3 MOZAMBIQUE, BASIC MINING SECTOR DATA (meticais)

\begin{tabular}{|c|c|c|c|c|c|c|c|c|c|c|}
\hline & & 1980 & 1981 & & & & 1985 & 1986,1 & 987 & \\
\hline \multicolumn{11}{|c|}{ 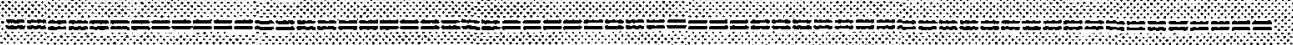 } \\
\hline $\mathrm{GPP}$ MIn⿴囗ng & G. & l, & 1.6 & $1+4$ & 2 & & $1 \%$ & & 19 & 1.0 \\
\hline $8, G D P M 1$ & 8 & 1.58 & 188 & 14 & 138 & 28 & 18 & 18 & 28 & 12 \\
\hline Mneral & 10 & 100 & 966 & & & 362 & 234 & 236 & 875 & 111 \\
\hline $\mathrm{Ml}_{1}$ / prod/cap & USD & 108 & $2+2$ & 1 & 1. & $\$ 6$ & 14 & 1.4 & 12 & \%? \\
\hline$M+n$ Exports & 1\% & 437 & 421 & 22 & 19 & 106 & 126 & 110 & 188 & 1096 \\
\hline 8 м1 neral & $\mathrm{rts}$ & 488 & 428 & 2.58 & 1 & 1198 & 0,88 & 3,48 & $017 \%$ & 20 \\
\hline
\end{tabular}

Source IMR SADCE Databank 1990 .

At Independence in 1975 the mining industry was totally in private hands. In 1978 and 1979 all of the mining companies were nationalised. At this time mining came under the Ministry of Industry and Energy and two state mining companies were created to run the new acquisitions: Carbomoc for coal and MAGMA (Empresa Nacional de Minas) for other minerals. In 1983 the Ministry of Mineral Resources (Mirem ${ }^{4}$ ) was formed with responsibility for mineral exploration and exploitation. Mirem has under it the National Institute of Geology (ING5 ${ }^{5}$ geological survey), the National Directorate for Hydrocarbons ( $\mathrm{DNH}^{6}$ : for gas and oil), the Coal Cabinet (GPC: for coal) and the National Directorate of Mines (DNM ${ }^{7}$ : for other minerals). In addition to the two state companies mentioned above, a state 
company for semi-precious stones (GPL) was created and in 1980 the National Hydrocarbon Company (ENH) was formed to handle oil and gas exploration and exploitation contracts. Recently, the possibility of setting up a state Minerals Development Corporation has been under consideration, which would be the state holding company for joint ventures with private capital and take over certain of the existing state companies. Since 1986 the government has been actively encouraging private investment in mining.

Table 4. MOZAMBIOUE MINERAI EXPORTS $1978,1980,1984$ \& 1988 (Mmeticais)

\begin{tabular}{|c|c|c|c|c|c|c|c|c|c|}
\hline \multirow{3}{*}{ Mrneral } & \multicolumn{2}{|c|}{1928} & \multicolumn{2}{|c|}{1980} & \multicolumn{2}{|c|}{1984} & \multicolumn{2}{|c|}{1988} & $\mathrm{Rank}$ \\
\hline & value & vol & yalue & 101 & value & v०1. & $0 a 14 \theta$ & 101. & 1988 \\
\hline & & & & & $m-$ & & 58 & 5 & \\
\hline $\mathrm{Asbestos}(\mathrm{kt})$ & 301 & 0,42 & 1010 & 0121 & 213 & 0024 & 0085 & $0 \% 0$ & 2 \\
\hline Bauplte $(\mathrm{kt})$ & $0+$ & $0 \%$ & 0 ?. & 0 & $0 \%$ & 0 & 4511 & $6 \% 5$ & 1 \\
\hline Bentonlte $(\mathrm{kt})$ & 0,53 & 1055 & 1004 & 0061 & 0008 & 0002 & 14466 & 0.26 & 6 \\
\hline Bery $(t)$ & 0,36 & $31 \%$ & 10052 & $33 \%$ & 0048 & 17 & 2ै? & $10+$ & \\
\hline coll 1 tt & 4130 & 38,8 & 121,70 & $98 \%$ & 22,60 & $15 \%$ & 2951 & 149 & 2 \\
\hline coppert $(k t)$ & 2,21 & 1220 & $12+53$ & 1240 & 33 & 110 & 157.68 & $0 \% 59$ & 1 \\
\hline Mard 1 e $(13)$ & $0 \%$ & $0 \%$ & $0 \%$ & 00 & 0 & 0 & 223,53 & $78 \%$ & 3 \\
\hline SPP stonest & 001 & +ै & 18,09 & ४ै & 1107 & ४ै & 52.64 & \%? & 5 \\
\hline pantal $t_{e}(t)$ & 44,10 & 482 & 163,10 & 44,0 & 5800 & 24,0 & $00+$ & 0 & \\
\hline others & 29880 & २ै & 2139 & ?४ & 0,50 & २? & 0 & 0 & \\
\hline
\end{tabular}

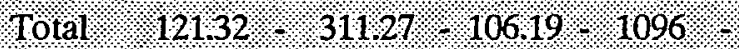

\% copper concentrate $(20 \% \mathrm{Cu})$. + semi-precious stones, 1 tantalite concentrate. Note: neither tantalite nor asbestos were produced in 1988, exports were made from stocks. Source. Mirem 198677819.

\section{Economic Geology}

An interesting aspect of the geology of Mozambique is that, for the centre and south of the country, the geological and political borders are virtually the same. Whether this was because the mining magnate Cecil John Rhodes had realised the relationship between the stable cratons and mineral resources or whether the highlands were considered preferable due to their mild climate and absence of tropical diseases, particularly malaria, is not known, but either way the borders of southern Mozambique correspond to the limits of the infertile sandy Cretaceous to Recent low-lying sediments containing few mineral resources (except natural gas), while Zimbabwe and South Africa contain the whole of the two major mineral-rich stable cratons within them, the Zimbabwe craton and the Kaap-Vaal craton.

The oldest rocks in Mozambique are the extension of the Archaean schistbelt from Zimbabwe across the border in Manica Province in the centre of the country. This belt is also known as the Mutare gold belt and contains most of the country's gold resources and also has deposits of copper, asbestos, lead, iron ore and nickel. The next are the meta-sediments of the Gairezi and Umkondo groups, also on the frontier with Zimbabwe, which host deposits of copper and limestone. The extension of the Limpopo from Zimbabwe contains metamorphosed cratonic rocks with few mineral occurrences.

Most of the centre and north of Mozambique contain rocks virtually exclusively of the pre-Cambrian "migmatitic-gneissic complexes" (mobile belts) which contain metamorphosed volcano-sedimentary sequences in Zambezia province with numerous pegmatites containing tantalum, niobium, lithium and felspar, except for the Metangula Karroo Graben in the north-west and the Rovuma Basin in the northeast while Tete Province contains the Karroo sediments (coal-bearing) of the Zambezi Rift and preCambrian rocks of a "migmatitic-gneissic complex". The younger sediments of the south and the northern coast contain limestones, diatomite and, still under formation today, heavy mineral beach 
At Independence in 1975 most of the country was geologically unknown. Virtually all deposits had been found by hunters and prospectors and less than two-thirds of the country had been mapped at 1:250,000 scale. Large areas of the north had not even been topographically mapped. The primary task on gaining Independence was therefore one of surveying the country in order to assess the mineral potential. In this respect large advances were made from 1975 to 1983 when most exploration work had to be abandoned due to the increasing South African sponsored banditry in the countryside.

Tables. MOZAMBIOUEGEOLOGICAT EXPLORATION A CTVITY (thousand $\mathrm{km}^{2}$ )

\begin{tabular}{|c|c|c|c|}
\hline Hetivity & Pre 1975 & $1975-1985$ & 8 \\
\hline \multicolumn{4}{|c|}{ Geologlical Mappling } \\
\hline $1,250,000$ & 467.42 & 478.59 & 51. \\
\hline $1.100,000$ & 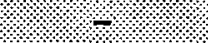 & 345.00 & 100 \\
\hline $10,50,000:$ & 2 & 35.00 & 100. \\
\hline \multicolumn{4}{|c|}{ Althorne Geophysical luappings: } \\
\hline $1 \% 250,000$ & 496,02 & 47665 & 49. \\
\hline $1.100,000$ & 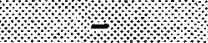 & 476.65 & 100 \\
\hline $1.50,000 \%$ & \%. & 12.68 & 100 \\
\hline \multicolumn{4}{|c|}{ Geochemical $/$ Mapplng } \\
\hline $1,250,000$, & 134,70 & 23.8 .30 & 6. \\
\hline $1.100,000$ & 3 & 66.00 & $100 \%$ \\
\hline $1.50,000$ & 6.63. & 1,08 & 52 \\
\hline Total $(\mathrm{r}, \mathrm{km} 2):$ & 1104,77 & 2135,95 & $66 \%$ \\
\hline
\end{tabular}

7.6 1975-85 of total. Source Kashamila 1985.

The majority (66\%) of systematic geological, geochemical and geophysical mapping of Mozambique has been done since Independence. This effort is all the more significant when considered against the virtually non-existent mineral exploration infrastructure left by the departing Portuguese colonial authorities. At Independence there were five professionals, three drillers, two draughtsmen and 13 trained assistants, all of them foreign except for 3 assistants. By 1985 there were 11 professionals, 23 draughtsmen and 330 qualified assistants, all nationals.

The main foreign companies working in exploration since 1975 have been: LKAB (Sweden), coal, tin and iron ore; BIC (Integrated Complex Brigade: USSR), pegmatites, coal, graphite and others; Limex (GDR), pegmatites and coal; Huntings (UK), airborne geophysical mapping and geological mappjing; BRGM, airborne geophysical mapping and geological mapping, and Aquater (Italy), geological mapping and titanium.

This large investment in exploration since 1975 had the following three objectives: a) The formation of a national skilled manpower base for mineral exploration; b) The creation of an inventory of mineral resources through geological exploration; c) The reactivation of the existing mining industry. Of these three the first two have been successfully pursued while some headway was made in reactivating existing mines before the deterioration of the security situation from 1981. In 1981 there were 52 geological brigades operating in various parts of the country. By 1990 there were virtually none.

\section{Legislation}

a) Minerals:

The Mining Law was enacted in April, 1986 is a relatively brief act, containing broad principles, and was supplemented by more detailed regulations promulgated in 1987 . Subsequent to the Moatize colliery 
disaster in 1977, extensive mining safety regulations, for both open cast and underground operations, were drawn up and issued in 1981.

To date contracts have been negotiated on a case by case basis using a model agreement developed by the National Directorate of Mines in consultation with the Technical Assistance Group of the Commonwealth Secretariat. The contracts follow the formulations used generally in the international mining industry, including both government participatory and non-participatory models.

In effect, there are two phases incorporated in each contract: the first, comprising the survey, exploration and feasibility periods, is governed by a Prospecting Licence; the second phase,comprising the mine development and production periods, is governed by a mineral concession. Both the licence and the concession are mineral specific, although provision is made for preferential rights to mine associated minerals as well as other minerals discovered in the course of operations.

During the term of the prospecting licence, the Agreement Area may be reduced or may be enlarged if the deposit proves to extend beyond the original borders. Depending on the mineral resource and the exploration operations being conducted, a specified percentage of the initial area may have to be relinquished during the course of the work and/or prior to any extension being approved.

All operation expenditures must be in convertible foreign currency, except that where Mirem participates in the venture, its participation may be calculated in any rights, benefits, infrastructure etc... contributed and in local currency for any expenditures such as local wages and services. A minimum work programme and budget is required for these initial expenditures with the provision that any shortfall be paid to Mirem. During the term of the prospecting licence, a mineral rights use rent calculated on the basis of the total surface area of the Agreement Area is collected. During the term of the Concession, a land use and occupation tax is payable under the Land Law and Regulations.

A royalty on production and income tax on profits must be paid. The royalty is not set by law but is negotiable. Provision is made for exemption from import and export duties and personal income tax for foreign employees resident in Mozambique less than a total of 180 days of a year. Profits are $100 \%$ exportable. An adjustment or exemption from any taxes is negotiable. All data resulting from the operations is the property of Mirem and is treated as confidential. Disputes, if not resolved by negotiation are subject to arbitration. Under the Foreign Investment Law of 1984 (Law No.4/84,.18 August, 1984) arbitration of disputes regarding the interpretation and application of the contract is done by an arbitration committee nominated by the two parties; failing that, by the International Chamber of Commerce in Paris.

A comprehensive training and preferential employment programme for Mozambican nationals is included and preference is also to be given to local goods and services, provided that they are of comparable quality, price and availability.

Thus the Mozambican legislation has become amongst the most "liberal" in the region, mainly in order to attract foreign investment despite the considerable security risks.

b) Hydrocarbons:

In 1981 the new law regulating petroleum activity was approved. Under it all concessions are given to ENH(state oil company) which is then permitted to enter into contracts with foreign companies for the exploration and development of the concession. The law also has regulations regarding the protection of hydrocarbon resources and the environment, gas flaring, petroleum export rights, the employment 
and training of national personnel and the use of local goods and services.

In 1983 and 1984 ENH entered into three production sharing contracts with oil transnationals (Esso/ Shell, Amoco and BP). The salient features of these contracts are: An initial exploration period of three years with two optional extensions of two years and $25 \%$ of the concession will be given up after the first 3 years and a further $25 \%$ after the first two year extension; a development period of 20 years, a $15 \%$ royalty on all production; an after tax and royalty profit division between the company and ENH according to the production sharing scale (variable); and, a tax exemption from essentially all tax except for industrial (company) tax at $50 \%$ of profits. Unfortunately none of these exploration programmes made any discoveries.

\section{Mineral Production General}

With the exodus of Portuguese personnel in $1975 / 6$ mineral production fell, but by 1981 output had recovered for most minerals, and for some production levels were well above those of the colonial period. With the rapid increase in banditry from 1982 production of all minerals slumped except for bauxite, marble, bentonite and salt.

Table 6. MOZAMBIQUE. MINERAI PR ODUCTION

\begin{tabular}{|c|c|c|c|c|c|c|c|c|c|c|c|}
\hline Mreral & & 1913 & 1971 & 1981 & 1985 & 1986 & 1987 & 1988 & 1989 & $1973-81$ & 198188 \\
\hline & & & $\%$ & 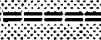 & 17 & $z$ & $=$ & 1 & $-1=$ & $y=-1-1$ & $-1-=$ \\
\hline Asbestos & $k t$ & .15 & 100 & 1,42 & 140 & 105 & .00 & 02 & 00 & 8488 & +998 \\
\hline Baul llte & kt & 800 & 00 & 100 & 35 & 3,92 & 5,07 & 600 & 124 & $\mathrm{nap}$ & nap \\
\hline венton & $k t$ & 2,99 & 264 & 12 & $\$ 90$ & $1+1$ & 109 & 1,00 & 13 & 168 & 1008 \\
\hline $\mathrm{Bery}$ & tt & 15.5 & 310 & 61 & 90 & 1,4 & 00 & 100 & 00 & 228 & $1100 \%$ \\
\hline B 1 smuthite & tt & 200 & 716 & 3.62 & 140 & 08 & 100 & 00 & 00 & 818 & $100 \%$ \\
\hline $0 \mathrm{al}$ & kt & $394 \%$ & 288 & 535 & 20 & 4 & 43.3 & 24,0 & 62.0 & $36:$ & 1968 \\
\hline Copper ponct & rt & $3 \% 18$ & 100 & 188 & 107 & 10 & 172 & 10 & $\$ 2$ & 728 & 208 \\
\hline retsteel & kt & 47.8 & 124 & 132 & 91 & 25 & 80 & 40 & ra & -728 & 1638 \\
\hline $\mathrm{Felspar}$ & kt & 183 & 182 & 1018 & 20 & 007 & 00 & 00 & 000 & 178 & 1008 \\
\hline KaO $1 \mathrm{n} n$ & kt & 10 & 20 & 30 & 57 & 15 & 114 & 00 & 00 ? & $197 \%$ & 1008 \\
\hline inst 1 cement & $\mathrm{kt}$ & 611 & 326 & 261 & 86 & 73 & 13 & 64 & na & -578 & 1758 \\
\hline Marble & 103 & 368 & 10 & 167 & 7860 & 1137 & 1140 & 1100 & $687 \%$ & -558 & $5: 598$ \\
\hline $\mathrm{MICa}$, & $\mathrm{kt}$ & 31 & .43 & 130 & 1,00 & 100 & 100 & 00 & .00 & 38 & 1008 \\
\hline sat & kt & $52 \%$ & 51.5 & $86 \% 4$ & 10.5 & 17.3 & 43.7 & 62,5 & na & 638 & 1288 \\
\hline Ta Mlcrol $1 \mathrm{ter}$ & te & 53,8 & 40,9 & 48,1 & 1004 & 2.6 & 100 & 00 & $00 \%$ & -108 & 1008 \\
\hline Ta tantal 1 tet & t & $30 \% 3$ & 376 & 34.1 & 152 & 2.7 & 00 & 00 & 00 & 138 & $1-1008$ \\
\hline
\end{tabular}

$+20 \% \mathrm{Cu}$ \%oncentrate. Source. IMR SADCC Database 1990

\section{Coal}

Coal is, under normal circumstances, the most important mineral in terms of both production and exports. In 1975 coal mining contributed $60 \%$ of total mineral production and $3.5 \%$ of national exports. By 1988 these figures had fallen to $27 \%$ and $0.5 \%$ respectively. Coal production fell from $575 \mathrm{kt}$ to $24 \mathrm{kt}$ over the same period. Coal exports in 1980 were $99 \mathrm{kt}$ worth 122 million meticais (3.8 MUSD), 39\% of total mineral exports. In that year tantalum pentoxide exports were worth more, at 164 million meticais (5MUSD), due to an exceptionally high tantalum price on the world market at that time. By 1989 coal exports had fallen $88 \%$ to $12 \mathrm{kt}, 21 \%$ of total mineral exports of one billion meticais (1.4 MUSD). The coal mines are in the Moatize Basin in Tete Province. They used to be owned by the Companhia Carbonifera de Mocambique, a subsidiary of Union Miniere (Belgium) but were nationalised in 1977 after a major colliery disaster in which 130 miners lost their lives. Since then they have been run by Carbomoc (state coal mining company) and technical services were provided by the German Democratic Republic until March 1990. There are four underground mines, each with an annual capacity of 
150 to $200 \mathrm{kt}$. The total installed capacity is $800 \mathrm{kt} / \mathrm{annum}$ of coking and steam coal (1:1). Since 1981 production has fallen radically (by $90 \%$ ) due to the sabotage of the railway from Moatize to the port of Beira. The only exports in 1989 were to neighbouring Malawi and Zimbabwe by road, but the former market will ultimately be lost as the Kaziwiziwi mine is developed in northern Malawi. Zimbabwe currently imports roughly $50 \mathrm{kt} /$ annum of low phosphorus and sulphur coke from South Africa as a reductant for ferrochrome production by Zimasco in Kwekwe. The Moatize coking coal has the correct characteristics and in this regard the SADCC Mining Sector has a project underway to assess the feasibility of establishing a coking plant at Moatize to supply Zimasco, funded by France.

Confirmed reserves in this basin are estimated at 490 Mtonnes and resources in the larger MoatizeMinjova basin are put at 5.5 Gtonne. Planned production, before the breakdown of the railway, was forecast at 1.8 Mtonnes worth roughly 50 MUS\$ in foreign exchange for 1986, increasing to 5 Mtonnes in 1995, almost all for export. Actual production in 1989 was roughly $62 \mathrm{kt}$. In 1989 a new plan, "Integrated Development of Coal" was drawn up which consists of two phases. Phase one is for the rehabilitation of the five underground mines to produce 0.8 to 1.0 Mtonnes/annum of metallurgical grade coal, to be done by Carbomoc with assistance from the Soviet Union and East Germany, buit it appears that the latter has withdrawn from its involvement in coal in Mozambique with the reunification with West Germany. The second phase entails the development of large opencast mines, as a joint venture with TNCs, to produce up to $25 \mathrm{Mtonnes/annum} \mathrm{of} \mathrm{ROM} \mathrm{coal} \mathrm{of} \mathrm{which} 10$ to $15 \mathrm{Mt}$ /annum will be saleable coal, about $60 \%$ of which will be of metallurgical (coking) grade. The middlings (waste) could be used for a thermal power plant but there are no immediate markets for the electricity, though in future power might be sent via the Cabora Bassa transmission line to South Africa.

The joint venture for the second phase will most probably be made up of Trans-Natal Coal Corporation of South Africa (a Gencor subsidiary) as the operator, CVRD of Brazil (state company) will undertake the technical and feasibility studies and Lonrho will carry out the initial testing using their South African coal mining subsidiary (Tweefontein United Collieries). The cost of whole project is estimated at 1.5 GUSD, including the rehabilitation of the $600 \mathrm{~km}$ of railway to the port of Beira and the upgrading of the terminal. Part of the metallurgical coal will be exported to Brazil to pay off Mozambique's 300 MUSD debt to that country. One commentator has however noted that it is....

"...strange that South Africa is now involved in a project which will restore the Beira railway, of which in previous years Pretoria was at the very least partly responsible in destroying". 19

A pilot opencast mine is being developed with Soviet financial and technical aid and should be operational by the end of 1990 .

Under normal circumstances the Mozambican market consumes 160 to $180 \mathrm{kt}$ of steam coal annually mainly by the Maputo power station. Due to the location of the Moatize mines it is cheaper however to import coal for Maputo from South Africa than to bring it from Moatize. In terms of the SADCC, it might be feasible to source this coal from Swaziland via the Goba line instead.

There are several other basins the most important of which are Mucanha-Vuzi Basin on the northern edge of Lake Cahora Bassa, Minjova Basin to the east of the Moatize Basin, the Sanangoe Basin south of Cahora Bassa Dam and, out of the Zambezi Rift, the Metangula Basin in Niassa Province and a small deposit near Espungabera on the Zimbabwean border. Most of these deposits are medium to high ash steam coal. In 1989 the coal resources in the Zambezi Rift were put at over 8 Gtonnes (Moatize-Minjova and Mucanha-Vuzi). However, all coal development plans await an improvement in the security 
situation.

\section{Pegmatites}

The most important product from the small scale pegmatite workings is tantalum. Most of the workings are in Zambezia and Nampula Provinces. The tantalum/niobium minerals produced are tantalite and microlite and are exported as a concentrate. Production of contained $\mathrm{Ta}_{2} \mathrm{O}_{5}$ increased by $40 \%$ from 1973 (33t) to 1981 (46t) before the operations finally closed down in 1987 after several bandit attacks including the abduction of 22 Soviet technicians in 1983, of whom four were killed. Planned exports, under normal conditions, for 1986 would have been 120 tonnes of $\mathrm{Ta}_{2} \mathrm{O}_{5}$ worth roughly 10 MUS\$ in export receipts, but due to the security problems only $5 \%$ of this figure was produced.

In 1975 the US Bureau of Mines estimated the Mozambican tantalum resources to be $4.4 \mathrm{kt}$ or $1.7 \%$ of the world total, but at this time the tantalum pegmatite areas of Mozambique had not been geologically mapped. The principal tantalum workings are Morrua, Muiane and Marropino in central Zambezia Province. The total $\mathrm{Ta}_{2} \mathrm{O}_{5}$ reserves at these three workings were estimated at $5.8 \mathrm{kt}$ in 1985 grading 735 ppm at Morrua and $160 \mathrm{ppm}$ at Marropino and Muiane and further reserves at Mutala and other pegmatites are estimated at $1.7 \mathrm{kt}$. Since $1986 \mathrm{Mirem}$ has been trying to interest foreign companies in the tantalum deposits and although substantial interest has been shown, including Soviet, US and South African companies, nothing can be finalised until the security situation in the area improves.

In addition to tantalum minerals, the pegmatite workings produce semi-precious stones (emeralds, morganite, topaz, tourmaline, aquamarine), monazite, mica scrap, industrial beryl, and pollucite ( $\mathrm{Li}$ ). The lithium minerals are stockpiled at present for lack of a market.

\section{Copper}

All copper production comes from the Mundonguara Mine (ex Edmundian Mine) in Manica Province near the Zimbabwean border, $13 \mathrm{Km}$ west of Vila de Manica. The mine used to be run by Lonrho from Zimbabwe who stopped production in 1976 when the border with Zimbabwe was closed. Pre 1976 production was about $3.2 \mathrm{kt}$ of copper concentrate $(22 \% \mathrm{Cu})$ per annum, but it is thought that these figures were inflated to cover for production from Zimbabwe (Inyati Mine) in order to get around the UN sanctions against that country at the time.

The government reopened the mine in 1977 and since then production has been running at about 1000 tonnes of concentrate per year. In 1986 a contract was signed with the Zimbabwean state company, Mhangura Copper Mines (MCM), for the refining of the concentrate at their Alaska refinery, making it the second regional beneficiation project whereby more of the value-added remains in the region. However, in 1990 Mirem was reported to be considering closing the loss-making operation down, or at least privatizing it.

\section{Other Minerals}

Anthophillite asbestos production at Mavita, south-west of Chimoio, stopped because no markets have been found for the product since the asbestos-cement factory in Beira ceased operations as a result of the closing of the Beira cement plant, in turn due to the security situation at the limestone quarry (Mwanza). In 1985 the mine suffered a major bandit attack in which most of the plant and equipment were destroyed.

Garnets are at the Cuamba gamet mine outside the town of Cuamba in Niassa Province. The alluvial deposit is mined byopencast methods and the garnets are hand picked from the ore. Production was 3.54 tonnes of gem grade garnets and 6.45 tonnes of "waste" garnets in 1973. This had fallen to 2 tonnes of gem grade and 6.2 tonnes of "waste" by 1989 . In 1984 prognostic reserves were put at 80 tonnes of 


\section{garnets.}

The Boa Esperanca kaolin deposit is situated in Ribaue District in Nampula Province. The deposit has been mined since 1952 by opencast manual methods. The kaolin is washed and sorted at the mine site. Production of kaolin increased from 100 tonnes in 1973 to 297 tonnes in 1981 before falling to 152 tonnes in 1985 when production stopped due to the deteriorating security situation. Up to 1983 felspar was also produced from the deposit but reserves were exhausted in that year. From 1984 to 1986 felspar was produced at the open-cast manual operation at Tulua near the Port of Nacala in Nampula Province, but the operation closed down due to the security situation.

The Montepuez marble deposit is located $5 \mathrm{Km}$ north of the district capital of the same name, in Cabo Delgado Province. The quarry is particularly known for its "snow white" marble but other types are also produced. In 1989 the quarry produced $687 \mathrm{~m}^{3}$ of marble, 63\% for export. The operation is run jointly between Magma and an Italian company (Technostone SpA), which also does the marketing. Reserves are estimated at 30 thousand cubic metres. A major expansion of the operation is planned which will increase capacity to 15 thousand $\mathrm{m}^{3}$ perannum and for the establishment of a cutting and polishing plant in Pemba to produce $300,000 \mathrm{~m}^{3} /$ annum of slabs and tiles for export. The Monte Mataca "black granite" (gabbro) deposit, in Manica Province $30 \mathrm{~km}$ from the Beira corridor is also being assessed for export via Beira.

The Luzinada bentonite deposit is situated $35 \mathrm{Km}$ south-west of the capital city of Maputo. Production started in 1967 and it is an opencast operation using front-end loaders. The ore is milled, dried and activated with sodium carbonate near the mine site. Its main uses are the foundry industry, as an insulator in the construction industry, as a lubricant for drilling and it is used in animal feeds. Installed treatment capacity is $6 \mathrm{kt} /$ annum and in 1989 production was 126 tonnes, 91\% down on 1982 (1455 tonnes) due to security problems in the area. In 1989 reserves were put at $8452 \mathrm{kt}$. Negotiations have been held with several foreign companies, including $G$ \& W Industrial Minerals of Zimbabwe, with a view to turning this operation into a joint venture or to privatise it completely. Due to its importance as the only regional alternative to South African supplies to the SADCC states a SADCC Mining Sector sponsored study was carried out on the deposit which concluded that it was a low grade bentonite that could however be used for certain applications in the region.

Mozambique has three cement plants: one in the south outside Maputo (Matola), one in the centre outside Beira (Dondo) and one in the north at the port of Nacala. In $1978185 \mathrm{kt}$ worth 5.6 MUS\$ were exported and $354 \mathrm{kt}$ were produced. By 1988 production had declined to $64 \mathrm{kt}$ using imported clinker due to the closure of the limestone quarries supplying the Matola and Dondo plants. Production of asbestos-cement sheeting peaked in 1977 at nine thousand $\mathrm{m}^{3}$ before falling to 2.2 thousand $\mathrm{m}^{3}$ in 1988 . Mozambique has ample limestone resources and in 1989 total national reserves were put at 39 Mtonnes. Reserves for the Maputo and Beira plants have been secured for the next 20 years while those of the Nacala plant quarry are under investigation. The limestone at the Muanza quarry (for the Dondo plant), is thought to be suitable to substitute for a special grade of burnt lime currently imported from South Africa for ferrochrome manufacture at Zimalloys in Zimbabwe. Tests will be carried out as soon as the security situation allows.

In December 1984 a contract was signed with E.C. Meikle (Pvt) Ltd. of Zimbabwe whereby their bauxite mine (Alumen) on the border of Mozambique at Penhalonga could mine the extension of the deposit into Mozambique, making it the first (and so far only) SADCC cross-border mining operation by a local company. In $19897.2 \mathrm{kt}$ were produced. The bauxite grades about $60 \% \mathrm{Al}_{2} \mathrm{O}_{3}$ and is used for the production of aluminium sulphate for water treatment by Zimphos (owned by Chemplex, an AECI 
company in turn owned by $A A C$ ) in Zimbabwe. A SADCC study on the possibility of setting up an alumina/aluminium industry in the region concluded that the deposit was not suitable for this purpose and should continue to be used for aluminium sulphate production.

From the above discussion it is apparent that the Mozambican mining industry was small and underdeveloped even before the contraction since 1981 due to the deteriorating security situation. With the exception of coal and copper, most mining is at an artisanal level using opencast labour intensive methods.

\section{Hydrocanons}

Alimited amount of oil and gas exploration took place before Independence mainly in the onshore and nearshore areas between Maputo and Beira by Gulf, Amoco, Aquitaine, Hunt and Sunray. During this period three gas fields were discovered, at Pande ( 32 billion $\mathrm{m}^{3}$ ) and two smaller deposits at Buzi and Temane, but were not developed at the time. In 1980 the state oil company, ENH, was created to supervise hydrocarbon exploration and in the same year a new petroleum law was passed and a model production sharing agreement was drafted. ENH has negotiated a contract with the.JSSR (Tecnoexport) to do a re-evaluation of the Pande gas deposit by seismics and drilling to confirm the reserves of the known Pande field and to investigate a possible additional field close to Pande. The project will go ahead as soon as the security situation allows. Soon after the formation of ENH contracts were negotiated with Western Geophysical and the Geophysical Company of Norway (GECO) for a speculative survey over the whole length of the continental shelf. In addition, the Japanese state oil company, JNOC, completed a shallow-water seismic survey of Bazaruto Bay in 1984 and ENH have done an extension to this south of Beira, with promising results. Lake Niassa (Malawi) has also been seismically surveyed by Duke University of the USA.

In 1983 and 1984, ENH signed exploration and production contracts with four oil companies. Esso/Shell took an onshore concession in the Rovuma Basin on the border with Tanzania and after detailed seismic surveys in 1985 they drilled a $3.8 \mathrm{~km}$ dry hole near Mocimboa de Praia in 1986. ENH are continuing the work and in 1989 they signed a joint exploration agreement with the Tanzania Petroleum Development Corporation (TPDC) for work in the Rovuma Basin which extends across the border. This is the first exploration agreement between SADCC states.

Amoco took four blocks off the Zambezi delta where Hunt drilled two (dry) wells in the early seventies and BP Petroleum Development took a concession offshore over the African Rift extension in southern Mozambique off the mouth of the Limpopo River where they drilled an exploratory hole in 1987 and, with Amoco, are expected to sink a second hole.

\section{Prospects}

There are significant reserves of heavy mineral sands (titanium) on the beaches of Mozambique particularly between the port of Quelimane and Angoche. In 1959 and 1960 ilmenite from Pebane was exported to the UK. A large deposit was located off the Zambezi delta in 30 to $60 \mathrm{~m}$ of water in the early seventies, by the Geological Survey of West Germany, containing $55 \mathrm{Mt}$ of heavy minerals ( $91 \%$ ilmenite). From 1983 to 1986 Aquater (Italy) assessed the reserves in the Quelimane area and provisional estimates are $24.9 \mathrm{Mt}$ grading $9.61 \%$ economic heavy minerals ( $94 \%$ ilmenite). A study of the dunes and beaches around the mouth of the Limpopo determined 18 Mtonnes of economic heavy minerals grading $3.5 \%$.

Exploration work was carried out by a Yugoslavian team (Geoloski Zavod) in the Angoche (Congalone) area which came up with $28 \mathrm{Mt}$ grading $7.8 \%$ of economic heavy minerals (5\% cut-off grade). Kenmare Resources, a Dublin based loss-making subsidiary of Cluff Minerals, did further work on the 
deposit with Mineral Deposits Limited (MDL) of Australia and reserves are now estimated at $167 \mathrm{Mt}$ grading $3.25 \%$ heavy minerals. Kenmare is going ahead with a 100 MUSD project to exploit the deposit under a joint company (71.25\% Kenmare, $25 \%$ state, 3.75\% Geoloski Zavod) and, once operational in 1992 , annual revenues will be about $44 \mathrm{MUSD} /$ annum over the 10 year initial life of the operation which will have its own port. Kenmare is also considering a 60 MUSD plant to convert the ilmenite into synthetic rutile. The project includes provision of $760 \mathrm{kUSD} / \mathrm{an}$ for a security force made up of a Mozambican army detachment under the control of a British security company, to protect the operation from the MNR bandits.

Edlow Resources (USA) has signed a contract with Mirem for the assessment of the titanium sand deposits in the Moebase area in 1990. A SADCC project to study the feasibility of setting up a regional titanium oxide plant based on the heavy mineral beach resources of Mozambique, Tanzania and Malawi (lake shore), still awaits funding.

In 1986 Lonrho PLC signed a contract with Mirem, valid for 25 years, for exploration and mining rights for gold in six blocks in Manica Province on the border with Zimbabwe. In the first phase a joint mining company called Minas Auriferas de Manica (Manica Gold Mines, 20\% State, $80 \%$ Lonrho) was formed to carry out operations. The blocks contain primary deposits of gold in the extension into Mozambique of the Mutare Gold Belt. Lonrho's Redwing gold mine in Zimbabwe is on the other side of the border near Penhalonga and exploration work has been carried out by Lonrho Zimbabwe although the contract is with Lonrho PLC in London. This area has several old gold mines (over 30) that were worked in the past. Several areas, where access was possible, have been assessed and feasibility studies are being carried out. Lonrho have formed their own security organisation, which works jointly with the Mozambican army.

In 1988 a second company, Aluvioes de Manica Limitada (Alma) was formed (20\% State, $80 \%$ Lonrho PLC) to explore the alluvial deposits in the same area and Lonrho has recently announced that it will start up a dredging operation that will produce 20 to $25 \mathrm{~kg} /$ month of gold from $50,000 \mathrm{~m}^{3}$ of washed gravels on the Chua River. Lonrho operated a dredge on the Revue River (Revue Dredging Co.) in the forties which closed due to an exhaustion of accessible reserves, but only dredged to $6 \mathrm{~m}$ (reserves extend to $30 \mathrm{~m})$.

Deposits of high grade diatomite earth occur in Maputo (Boane) and Manhica Districts. In 1990 Cluff Minerals PLC, together with Rockwood Holdings PLC signed a contract with Mirẹm (40\% Cluff, 40\% Rockwood, 20\% Mirem) for the appraisal and possible development of a diatomite deposit $70 \mathrm{~km}$ north of Maputo. Neighbouring South Africa offers an excellent market as it consumes about $18 \mathrm{kt} / \mathrm{annum}$, 95\% of it imported from the USA.

Several foreign mining companies (Soviet, US and South African) have shown interest in the vast tantalum-niobium pegmatite field of central Zambezia Province, but nothing can be finalised until the security situation improves. There arealsoa string of pegmatites containing significant rare earth grades west of the Ta-Nb pegmatites in Zambezia and Nampula Provinces. They haveyet to undergo systematic geological appraisal which would be difficult to carry out under the present security situation.

Flake graphite deposits occur in numerous locations in the centre and north of the country. Graphite was mined on and off from 1911 in Tete (Angonia) and Nampula Provinces but all operations were abandoned in the early fifties. The most promising deposit in terms of both grade and infrastructure is situated at Ancuabe near the mouth of the Lurio River, south of the port of Pemba. Reserves for this deposit are estimated at 35.5 Mtonnes of flakey grade graphite with 15 to $20 \%$ carbon. A joint company 
has been set up (Kenmare 40\%, Shamrock Mining 30\% and state 30\%) to assess and exploit the deposit. An apatite (phosphate) occurrence near Monapo on the line of rail south-west of the port of Nacala has recently been surveyed by Intergeo (Czechoslovakia). The ore grades $9 \% \mathrm{P}_{2} \mathrm{O}_{5}, 7 \% \mathrm{FeO}, 4 \% \mathrm{MgO}$ and $1 \% \mathrm{TiO}_{2}$. Reserves of phosphate are put at $15 \mathrm{Mtonnes.} \mathrm{The} \mathrm{area} \mathrm{also} \mathrm{has} \mathrm{a} \mathrm{good} \mathrm{infrastructure} \mathrm{in} \mathrm{terms}$ of rail and road access and electricity supply, and will hopefully in the future form the basis for a fertiliser plant.

The Honde iron ore deposit was assessed by a Swedish team (LKAB) in the late seventies and reserves are estimated at $124 \mathrm{Mt}$ of low phosphorus and sulphur ore. This deposit has been considered as the feed for a direct reduction plant at Beira using natural gas or at Tete using coal and a 1986 study on the steel industry in the PTA/SADCC region concluded that the latter (Beira) should be considered as the next source of regional steel once demand had outstripped Zisco's capacity. The sponge iron produced would be made into steel using electric arc furnaces and in 1984 the Mozambican foundry in Maputo, Cifel, investigated the purchase of two 26 -tonne furnaces and a continuous billet caster ( $80 \mathrm{kt} / \mathrm{an})$ to supply feed for its rolling mills which can handle $50 \mathrm{kt} /$ annum and are being rehabilitated with Spanish aid. The project is still on ice due to the security situation in the Honde area.

Cassiterite (tin) has been mined intermittently from the Inchope deposit since 1919, but ceased in the late fifties. This deposit, of pegmatite origin, is situated close to the line of rail and the main highway between Chimoio and Beira in the centre of the country. The area was re-surveyed in 1978 and significant anomalies of tin, tantalum and niobium were encountered. Grades of 390 to $680 \mathrm{~g} / \mathrm{m} 3$ of tin and $25 \mathrm{~g} /$ $\mathrm{m} 3$ of $\mathrm{Ta}-\mathrm{Nb}$ were found over a wide area. Mirem is currently looking for finance for a detailed evaluation of this resource, but since the collapse of the tin price in 1985 there has not been much interest shown.

There are several other prospects for which Mirem has been looking for potential investors/partners. These include the Mt Muambe carbonatites, the Djanguire and Mt Domba fluorites and the polymetallic deposits of the Mueda Plateau in Cabo Delgado, but as yet not much interest has been shown.

Table 7 MOZAMBIOUE, PRINCIPAI MINERAL RESOURCES.

Mineral
Resources

+ author's guesstimate? $\% 35.5 \mathrm{Mt}$ at $15.20 \%$ carbon:

Sources. CNP 1989, UNDP 1986, DSGM 1974.

In 1983 ENH commissioned a feasibility study on the Pande natural gas resource by Fluor Corp. and Arthur D. Little. This study concluded that an ammonia plant producing $365 \mathrm{kt} / \mathrm{annum}$, located on the coast at Inhassoro, would be viable. The study was for a self-sufficient operation with its own power generation and processing local groundwater in the plant, with its own marine facilities. In 1984 the total 
investment needed was 182 MUS\$ of which pledges for 66 MUS $\$$ had been secured. The project has also been taken up as a regional project by the SADCC industrial coordination division and both the World Bank and the African Development Bank have shown interest, but no progress has been made in the creation of a SADCC facility. In 1987 talks were held with the Zimbabwean state IDC for a possible joint venture to replace the high-cost ammonia operation at Sable Chemicals, but appear to have come to nothing. In 1989 ENH held discussions with Anglo American, its subsidiary AECI, and the state oilfrom-coal company SASOL, with a view to obtaining capital and expertise for the setting up of a plant based on the Pande deposit. ENH also commissioned the American company Bechtel to do a study on the possibility of using the gas to make petrol and diesel, but no decision has been made in this regard.

\section{Discussion}

In 1975 the Mozambican mining industry was both undeveloped and backward and the geology (and hence the mineral potential) of the country was only superficially known. The few mines that existed were generally using artisanal, labour intensive methods. The first priorities of the new socialist government, in the minerals field, were: 1) to keep the existing mines operational in the face of abandonment and the exodus of Portuguese artisans and technicians; 2) to launch an extensive mineral exploration program in order to assess the national mineral potential; and, 3) To train the necessary manpower to effectively carry out the above two.

By 1981 all the mines had been nationalised and mineral production was once again reaching pre-1975 levels, with technical aid from the socialist countries, principally the Soviet Union and the German Democratic Republic, and internationalist volunteers. Exploration activity had covered over $90 \%$ of the the country and several new (and some old) mineral resources had been systematically assessed, again with socialist aid. Manpower development had progressed rapidly, to the stage where there were several times more qualified nationals than the pre-1975 total of settlers and nationals. The battle on all three fronts appeared to be well in hand if not virtually won.

However, after the Independence of Zimbabwe, in early 1980, the South African regime took over the running of the MNR, which had been the creation of the Rhodesian security forces, and with their considerably more extensive resources for the training and supply of the bandits, the destabilisation war was rapidly escalated. By the end of 1983 virtually all mineral exploration activity had been abandoned and the mining industry was collapsing, both due to the banditry in the countryside.

The government then attempted several compromises in an effort to halt the rapid disintegration of the economy. The first was the Nkomati Accord of March 1984 whereby they tried to halt or at least diminish South Africa's sponsorship of the bandits and to increase its stake in the Mozambican economy principally in their traditional (pre-1975) areas of invisibles, namely, ports/rail, miners and tourism. At the same time a Western diplomatic offensive was launched with the objective of getting the OECD states to use their leverage on South Africa tocease running the bandits and to exploit the contradictions between Western imperalism and South African sub-imperialism. To achieve this, a new policy of encouraging Western foreign investment was launched to the extent of part-privatising state enterprises, but generally to be run as joint state/TNC operations. The foreign investment regime was changed to the degree that it is now more favourable than those of most neighbouring countries. Repatriation of after tax profits is $100 \%$ for Mozambican mining companies, $50 \%$ in Zambia and a mere $35 \%$ in Zimbabwe.

Until 1989, the results of these two strategies had been mixed: In South Africa's case there had been only 
a marginal decrease in their support to the bandits and an insignificant increase in their involvement in the port of Maputo, tourism and the recruitment of miners. Regarding the West, there has been. increased pressure from some quarters on South Africa to stopits destabilization policy, but to no great effect, while there has been significant interest in the opening up of the economy to foreign investment, though not much action, mainly due to the security situation. In a negative sense, it can be argued that the government has achieved the victory of the USA not openly recognising and supporting the MNR, as they have in UNITA's case in Angola.

The only foreign investment contracts signed to date are for petroleum (Esso/Shell, Amoco and BP), where the process started as far back as 1983, gold (Lonrho) which lies within the relatively secure Beira corridor zoneand titanium sands (Kenmare) on the coast. South African concerns have shown interest in both the diatomite and bentonite resources of Maputo Province, the tantalum pegmatites in Zambezia and the Pande gas.

Since theadvent of "pretoriastroika" in 1990, official South African government support to the bandits appears to have stopped, but support is reported to be continuing from private sources in that country. Mozambique's late president, Samora Machel's, claim in 1975 that Mozambique would never be free until South Africa was free appears today to have been more true than seemed at the time.

At a regional level (SADCC), the proposed urea plant based on Pande natural gas has been taken up as a SADCC project, but with little concrete action. It has also been considered as a joint Mozambique (ENH) - Zimbabwe (IDC) project, but this idea has not been developed. The establishment of the region's second iron production plant (DRI sponge iron) based on Honde ore and Pande gas has been considered. A project for the assessment of Mozambique's lime resources has been completed and recommended that the Muanza (Dondo) deposit be assessed for metallurgical quality for export to Zimbabwe. Mozambican copper concentrates have been refined in Zimbabwe since 1986 and Mozambican bauxite is being mined by a Zimbabwean company and treated at a plant in Zimbabwe. Further areas of collaboration are under investigation such as the possible supply of activated carbon (coconut shells) to Zimbabwe. However, it now appears that the Mozambican mineral potential is likely to be realised by the South African mining TNCs, particularly AAC and Gencor.

In conclusion, Mozambique has extensive mineral resources, but their development is dependent on an improvement in the security situation. Nevertheless some "defensible" projects are going ahead, which will soon make the mining sector the nation's main forex earner. But this has been achieved at the cost of making the investment regime so advantageous to foreign companies that the state receives almost no rent. All that it receives is part of the forex employment and the development of the resource. 


\section{Footnotes}

1 CNP 1984.

2 World Bank 1990, page 178.

3 Programa de Reabilitacao Economica.

4 Ministerio de 4Recursos Minerais

5 Instituto Nacional de Geologia

6 Direccao Nacional de Hidrocarbonetos

7 Direccao Nacional de Minas

8 Kashamila 1985.

9 GPRM 1984.

10 ENH 1986.

11 ENH 1985.

12 Project 2.0.4 "Manfacture of Coke at Moatize Colliery".

13 CNP 1985 and 1989, page 10.

14 Run of Mine.

15 Commonwealth Secretariat 1990, page 5-68.

16 Companhia do Vale do Rio Doce

17 Mining Journal 314/8064, 30 March 1990, page 250 and Mining Magazine 162/6, June $1990, \mathrm{p} 410$.

18 E\&MJ 09/1990, page 160.

19 Coal Monitor No. 3, 2/1990, page IV.

20 CNP 1989, page 10.

21 Personal communication with the ex mine manager, 1986.

22 Now running on imported clinker.

23 CNP 1985 and 1989.

24 Austroplan 1990.

25 ENH 1986.

26 Mirem 1990.

27 CNP 1989, page 10.

28 Mirem 1986b.

29 Kenmare Resources Plc, Annual Report 1989, page 17.

30 Industrial Minerals, December 1989, page 60.

31 Silva \& Banze 1990, page 3.

32 Mining Journal, 314/8074, 8 June 1990, page 453.

33 This is a British Company, but all of its revenue comes from gold operations in Zimbabwe (Royal Family, Freda-Rebecca).

34 A British security company.

35 Cluff Minerals PLC, Annual Report 1990, page 17.

36 UNIDO 1986, page 85.

37 Mining Journal 341/8064, 30 March 1990, page 250.

$38 \mathrm{ENH} 1986$.

39 Industrial Development Corporation.

40 Mirem 1990. 


\section{(c) (1) (9)}

This work is licensed under a

Creative Commons

Attribution - NonCommercial - NoDerivs 3.0 License.

To view a copy of the license please see:

http://creativecommons.ora/licenses/bv-nc-nd/3.0/ 